\section{Universal foodstuff}

\section{Richard Davenport-Hines}

For God, Country and Coca-Cola: The Unauthorised History of the World's Most Popular Drink and the Company That Makes It. By Mark Pendergrast. Weidenfeld and Nicolson: 1993. Pp. 556. £20, \$27.50.

MARK Pendergrast writes in a breathless, enthusiastic prose that would be easy to tease. He has a Coca-Cola-centric view of world history that sometimes surpasses belief. Every great event is interpreted in terms of the world's thirst for this fizzy brown drink which is 99 per cent sugarwater with caramel colouring: "The Japanese didn't realize that by bombing Pearl Harbor, they were indirectly giving the Coca-Cola Company a worldwide boost that would ensure ... global dominance of the industry", he writes of US entry into the Second World War. "It's likely that the Japanese weren't thinking about soft drinks at all, although four Hawaiian Coke coolers were in fact martyred that day." Later on, the US civil-rights movement is reduced to the same level: "By demanding equal rights to CocaCola, the civil-rights activists were striking at the heart of Southern and American culture." Yet despite these recurrent absurdities, an excessive attention to detail and a tight chronological structure which means that trivia constantly interrupt the essential narrative, there are virtues in the book.

Pendergrast is a business journalist who grew up in Coca-Cola's home town of Atlanta, Georgia, on a street known locally as Coca-Cola Row. He has had access to the company's archives and interviewed a multitude of people associated with it, some of whom express themselves with surprising profanity. There are some good anecdotes, and many fascinating sidelights on the trashier side of American culture. The drink is traced from its origins in the $1880 \mathrm{~s}$ as a cocaine-laced panacea peddled by quacks for "neurasthenics" to a twentieth-century massdistributed cultural icon. Nowadays the multinational company has annual sales of $\$ 13$ billion: its chief executive was paid a salary in 1991 of $\$ 86$ million.

For medical historians there are several points of interest. The first is the early marketing of the drink as a "nerve tonic" for what Pendergrast calls the "turbulent, inventive, noisy, neurotic new America" of the $1880 \mathrm{~s}$, and his description of the advertising effort that went into pushing patent medicines. Conflicting and often inaccurate perceptions of cocaine are also described. Its cocaine content was tolerated when Coca-Cola was "a soda fountain drink for upper-class urban white professionals", but around 1900 scare stories of "Negro coke fiends" attacking
Beatle-juice - pop advertises pop.

their bosses or raping white women led to agitation against the beverage. In 1903 the cocaine ingredient was removed by the manufacturers, who in later years repeatedly denied under oath that the drink had ever contained cocaine. This official denial has continued into the 1990s.

The marketing of Coke typified what George Orwell called "Admass": the mix of mass culture with advertising in an appeal to the lowest common denominator. The company's annual budget for billion. "We're selling smoke", the creative staff of their advertising were always reminded. "They're drinking the image, not the product." Initially people drank it because it seemed naughty or even dangerous (even after the cocaine in the original formula was dropped). Advertising played on this. Pendergrast reproduces a 1907 promotional poster featuring an exhausted beauty, lying on a tiger-skin rug with her skirt rucked above her stockings and an empty Coca-Cola bottle beside her, with the advertising caption advertising and marketing now runs at $\$ 4$

"Satisfied". More recently, there has been a preference for a more clean-cut, familyorientated image, which is why the drink's cocaine-based origins are so forcibly suppressed by the company.

The turning point in the Coke story was in 1942. Coca-Cola had recently hired as head of its export department a man who had been campaign manager to President Franklin Roosevelt. He persuaded the US government to exempt the company from rationing, and, just as astonishingly, to let Coca-Cola build state-subsidized bottling plants wherever US troops were fighting. Coke thus acquired plants on every continent except Antarctica and an advantage that Pepsi-Cola has never been able to approach.

Coke's greatest reverse occurred in 1985 . The company was alarmed by PepsiCola making inroads of one per cent into its market share, and therefore changed its drink's flavour, marketing it as "New Coke". Consumers were revolted, not by the change of taste, but by the tampering with an icon. Coke for them had to represent permanence, stability and universality. "Changing Coke is like breaking the American Dream", complained one customer. "There are only two things in my life, God and Coca-Cola", wrote another: "Now you have taken one of these things away from me". Such emotional investment in a beverage does not fill Pendergrast with

despair. This failed marketing experiment was duly abandoned.

Noting that "the world's first coinoperated vending machine, invented in the first century $\mathrm{AD}$, dispensed holy water", Pendergrast compares Coca-Cola to "a new religion", and approvingly quotes an employee declaring that his job "is like being a representative from the Vatican, like you've touched God". Pendergrast continues: "The Coca-Cola religion has no morality, no commandment other than increased consumption of its drink". For him, "therein lies the true beauty of capitalism at its best". Given the identification of Coca-Cola with the American way of life, this book unwittingly gives a fillip to anti-American feeling by such naivety, cultural mediocrity and arrogance. It is though a case study of what is possibly the world's greatest marketing success, and gives a clear image of multinational corporate culture.

Richard Davenport-Hines is at 51 Elsham Road, London W14 8HD, UK. 